\title{
Allelopatic effects of Waltheria indica L.: Biocontrol potential in ecological restoration
}

\author{
Efeitos alelopáticos de Waltheria indica L.: Potencial de biocontrole na restauração ecológica \\ Efectos alelopáticos de Waltheria indica L.: Potencial de biocontrl em la restauración ecológica
}

Received: 09/30/2021 | Reviewed: 10/05/2021 | Accept: 10/07/2021| Published: 10/10/2021

Bruno Santos Francisco

ORCID: https://orcid.org/0000-0001-8586-3750

Universidade Federal de São Carlos, Brasil

E-mail: brunofrancisco@estudante.ufscar.br

Felipe Bueno Dutra

ORCID: https://orcid.org/0000-0002-6280-7307

Universidade Federal de São Carlos, Brasil

E-mail: fbdutra@estudante.ufscar.br

Emerson Viveiros

ORCID: https://orcid.org/0000-0002-0215-0585 AES Brasil, Brasil

E-mail: emerson.viveiros@aes.com

Raquel Passaretti

ORCID: https://orcid.org/0000-0001-6975-1505 AES Brasil, Brasil

E-mail: raquel.passaretti@aes.com

Rafael Paranhos Martins

ORCID: https://orcid.org/0000-0003-4264-3736 AES Brasil, Brasil

E-mail: rafael.paranhos@aes.com

Bruna Santos Teração

ORCID: https://orcid.org/0000-0003-3766-8672

Universidade Federal de São Carlos, Brasil

E-mail: bruna.teracao@estudante.ufscar.br

Lausanne Soraya de Almeida

ORCID: https://orcid.org/0000-0001-8689-580X

Universidade Federal de São Carlos, Brasil

E-mail: lausannesoraya@gmail.com

Larissa Rocha

ORCID: https://orcid.org/0000-0001-6560-1200

Universidade Federal de São Carlos, Brasil

E-mail: larissarochafe@ gmail.com

José Mauro Santana da Silva

ORCID: https://orcid.org/0000-0003-0662-4132

Universidade Federal de São Carlos, Brasil

E-mail: josemauro@ufscar.br

Fatima Conceição Márquez Piña-Rodrigues

ORCID: https://orcid.org/0000-0001-8713-448X

Universidade Federal de São Carlos, Brasil

E-mail: fpinarodrigues@gmail.com

\begin{abstract}
In Brazil, most degraded areas are occupied by exotic and invasive species, which require alternatives for their management. We evaluated the allelopathic effects of Waltheria indica in the laboratory from aqueous extracts of leaves and roots on the germination of the species Lactuca sativa L. (lettuce), Urochloa brizantha (Hochst. ex A.Rich.) RDWebster (brachiaria) and Handroanthus chrysotrichus (Mart. ex DC.) Mattos (yellow Ipe). We collected adult one-year-old Waltheria indica shrubs in ecological restoration areas by direct seeding. We used two treatments with aqueous extracts of leaves and roots and a control without extract, with ten repetitions of 10 seeds per treatment, totaling 600 seeds per test species. Germination and use of tetrazolium assays to evaluate the potential respiratory activity of the roots were used. The aqueous extract of W.indica leaves affected the number of germinated seeds of all test species, while the aqueous extract of roots affected only L. sativa and H. chrysotrichus. There were no significant differences between treatments (leaf and root extracts) in species germination. The aqueous extracts of Waltheria indica leaves and roots affected germination and cellular respiration of the studied species, mainly in Lactuca sativa. The identification of $W$. indica allelopathic compounds may be an initial step so that in the future new bioherbicides are produced from extracts of this species, or even that its seeds can be sown together with non-sensitive native species, aiming for control of exotic species in ecological restoration projects.
\end{abstract}

Keywords: Weed competition; Weed control; Germination; Urochloa brizantha. 


\begin{abstract}
Resumo
No Brasil a maioria das áreas degradas são ocupadas por espécies exóticas e invasoras, o que necessita de alternativas para seu manejo. Avaliamos os efeitos alelopáticos de Waltheria indica em laboratório a partir de extratos aquosos de folhas e raízes na germinação das espécies Lactuca sativa L. (alface), Urochloa brizantha (Hochst. ex A.Rich.) R.D.Webster (braquiária) e Handroanthus chrysotrichus (Mart. ex DC.) Mattos (ipê amarelo). Coletamos arbustos adultos Waltheria indica com um ano de idade, em áreas de restauração ecológica por semeadura direta. Utilizamos dois tratamentos com extratos aquosos de folhas e raízes e um controle sem extrato, com dez repetições de 10 sementes por tratamento, totalizando 600 sementes por espécie-teste. Ensaios de germinação e de uso de tetrazólio para avaliar a atividade respiratória potencial das raízes foram empregados. O extrato aquoso de folhas de W.indica afetou o número de sementes germinadas de todas as espécies-teste enquanto o extrato aquoso de raízes afetou apenas L. sativa e $H$. chrysotrichus. Não houve diferenças significativas entre os tratamentos (extratos de folhas e raízes) na germinação das espécies. Os extratos aquosos das folhas e raízes de Waltheria indica afetaram a germinação e a respiração celular das espécies estudadas, principalmente em Lactuca sativa. A identificação dos compostos alelopáticos de $W$. indica, pode ser um passo inicial para que no futuro novos bioherbicidas sejam produzidos a partir de extratos desta espécie, ou até mesmo que suas sementes possam ser semeadas junto com espécies nativas nãosensíveis, almejando o controle das espécies exóticas em projetos de restauração ecológica.
\end{abstract}

Palavras-chave: Mato competição; Controle de ervas daninhas; Germinação; Urochloa brizantha.

\title{
Resumen
}

En Brasil, la mayoría de las áreas degradadas están ocupadas por especies exóticas e invasoras, que requieren alternativas para su manejo. Evaluamos los efectos alelopáticos de Waltheria indica en el laboratorio a partir de extractos acuosos de hojas y raíces sobre la germinación de la especie Lactuca sativa L. (lechuga), Urochloa brizantha (Hochst. Ex A. Rich.) RDWebster (brachiaria) y Handroanthus chrysotrichus (Mart. ex DC.) Mattos (Ipe amarillo). Recolectamos arbustos adultos de Waltheria indica de un año en áreas de restauración ecológica mediante siembra directa. Se utilizaron dos tratamientos con extractos acuosos de hojas y raíces y un testigo sin extracto, con diez repeticiones de 10 semillas por tratamiento, totalizando 600 semillas por especie de prueba. Se utilizaron ensayos de germinación y uso de tetrazolio para evaluar la actividad respiratoria potencial de las raíces. El extracto acuoso de hojas de W.indica afectó el número de semillas germinadas de todas las especies de prueba, mientras que el extracto acuoso de raíces afectó solo a L. sativa y $H$. chrysotrichus. No hubo diferencias significativas entre tratamientos (extractos de hojas y raíces) en la germinación de las especies. Los extractos acuosos de hojas y raíces de Waltheria indica afectaron la germinación y respiración celular de las especies estudiadas, principalmente en Lactuca sativa. La identificación de compuestos alelopáticos de W. indica puede ser un paso inicial para que en el futuro se produzcan nuevos bioherbicidas a partir de extractos de esta especie, o incluso que sus semillas puedan ser sembradas junto con especies autóctonas no sensibles, con el objetivo de controlar especies exóticas. en proyectos de restauración ecológica.

Palabras clave: Competencia de los arbustos; Control de malas hierbas; Germinación; Urochloa brizantha.

\section{Introduction}

Brazil is one of the five countries with the largest hotspot area in the world (Brancalion et al., 2019). Despite its importance, the country has high rates of deforestation, which has generated initiatives with targets to restore 12 million hectares of degraded areas and forests by 2030 (Calmon, 2021). However, most areas intended for ecological restoration are highly uncharacterized from the point of view of the composition of native species, represented mostly by degraded pastures (Rodrigues et al., 2009). Many of these areas to be restored have strong coverage of exotic and invasive plants that end up hindering the establishment of native species, becoming a major cause of failure in ecological restoration (Cornish \& Burgin, 2005; García-Orth \& Martinéz-Ramos, 2011).

Regardless of the occurrence and type of interactions caused by these exotic and invasive plant species, measures need to be taken to suppress or reduce the number of these plants in the area to be restored to the condition of coexistence with native species (Copeland et al., 2021). However, the control of invasive alien species is one of the main challenges for ecological restoration (Durigan et al., 2013; Holl et al., 2014; Weidlich et al., 2020). Currently, control can be achieved by applying preventive, biological, physical, and chemical methods, and integration between different methods is the most common and effective way to control exotic and invasive weeds (Silva et al., 2009; Brighenti and Oliveira, 2011; Passareti et al., 2020; Di Sacco et al., 2021). 
Allelopathy is the process in which a plant produces chemical substances (allelochemicals) that can interfere with the growth and establishment of other plants (Lovett \& Ryuntyu, 1992; Li et al., 2011). In this context, biological control by allelopathy, can be an alternative in the control of exotic invasive species, favoring ecological restoration (Lopes, 2017; Iqbal et al., 2020). Allelochemical substances can bring an ecological and sustainable alternative for the control of exotic and invasive species such as bioherbicides (Rosa et al., 2007; Rigon et al., 2013).

In areas of ecological restoration by direct seeding, we observed that, specifically around sites where there are densities of individuals of the native species Waltheria indica L. (white mallow), the litter layer was relatively continuous throughout the year. At these sites, there is a significant reduction in the occurrence of brachiaria grass (Urochloa spp.), considered an invasive exotic species; however, native species appear to be growing normally.

Based on these field observations, this study aimed to verify the allelopathic activity of aqueous extracts of leaves and roots of the species Waltheria indica (malva branca) on the germination of the species Lactuca sativa L. (lettuce), Urochloa brizantha (Hochst. ex A.Rich.) R.D.Webster (brachiaria), and Handroanthus chrysotrichus (Mart. ex DC.) Mattos (yellow ipe).

\section{Material and Methods}

Entire adult shrubs of Waltheria indica were collected in one-year-old direct seeding ecological restoration areas in the municipality of Cardoso, São Paulo State, Brazil (22 K 616245.75 m E 7781497.42 m S), on the Tomazão stream, a tributary of Turvo River that flows into Rio Grande River. The climate in the municipality of Cardoso is Aw by Köeppen (1948), a tropical climate with a dry winter season, with two well-defined seasons: a dry season, represented by a six-month period (April through September), and a very wet season, also of six months (October through March). The average temperature is $24.6{ }^{\circ} \mathrm{C}$ and the average annual rainfall is $1227 \mathrm{~mm}$ (Climate-date, 2021).

To evaluate the allelopathic effect of plant extracts on seed germination, two aqueous extracts were made, the first using adult leaves and the second using roots of Waltheria indica (white mallow). The leaves and roots were dried in an oven with forced air circulation at $45^{\circ} \mathrm{C}$ (Melo et al., 2004), and after crushed. Deionized water was added at a temperature of $60^{\circ} \mathrm{C}$ to the dried and crushed material of each plant organ at a ratio of 2:10 (g/ml). The solutions were left to rest for $24 \mathrm{~h}$ for extraction of the compounds. After this period, the solutions obtained were strained through filter paper and stored in a refrigerator at $4^{\circ} \mathrm{C}$.

We selected as test-species the sensitive $L$. sativa cultivar aurelia to express the allelopathic effect, the invasive weed $U$, brizantha, and the native species $H$. chrysotrichus. We analyzed aqueous leaf and root extracts at the above mentioned concentrations in the germination bioassays. We utilized as control treatment, the filter paper moistened only with 6 ml of deionized water.

The germination tests were conducted in petri dishes with eight centimeters in diameter, lined with two layers of filter paper moistened with six $\mathrm{ml}$ of extract. Ten repetitions with 10 seeds each were used for each treatment (leaves, root and control), totaling 400 seeds per species. All treatments, discriminated by type of extract and control, were composed by 10 repetitions, were distributed entirely at random in a mangelsdorf-type germination chamber, at $25^{\circ} \mathrm{C}$, under 12 -hour lighting per day, maintained by four white fluorescent lamps. The germination test for lettuce seeds was conducted for 10 days and those of brachiaria and yellow Ipe for 15 days. At the end, the percentages of germination and the potential respiratory activity of the seedling's roots were evaluated. Seeds were considered germinated when they produced primary roots at least 2 mm long with geotropic curvature (Carmo et al., 2007).

To evaluate and estimate the potential respiration of the roots of the test-species seedlings, we used the tetrazolium test, which principle is the reduction of 2,3,5-tetrazolium triphenyl chloride through the activity of dehydrogenase enzymes, catalysts of respiratory reactions in cells, forming triphenylformazan, a red substance that indicates living tissues in which there is respiratory activity (França Neto, 1999). 
After pre-testing to define the most appropriate concentration and immersion time for staining, the roots were placed in black germination boxes containing tetrazolium solution ( $\mathrm{pH} 6.5$ to 7.0 ) at a concentration of $0.075 \%$ and placed in a $25{ }^{\circ} \mathrm{C}$ B.O.D. germination chamber for 4 hours in the absence of light. At the end of the incubation period, the tetrazolium solution was discarded, and the roots were washed in running water, remaining moist and in the dark. Then, each root was examined individually with the aid of a stereoscopic magnifying glass, analyzing the extent of the colored tissues.

Percentages of germination and potential root respiratory activity were calculated. The Mann-Whitney test was used to check differences in germination between the treatments and their respective controls, after testing for normality and homogeneity of the data at 5\% statistical significance. All analyses were performed in the program R (R Development Core Team 2021).

\section{Results and Discussion}

Allelopathic substances can be present and released by the stem, and especially by the leaves and roots (Piña-Rodrigues \& Lopes, 2001; Kremer et al., 2016; Ribeiro et al., 2019). These substances can often be volatile and or affect only a few species (Rice, 1984). In addition, the allelopathic effect may affect some part of the plant's development, such as germination, growth, or establishment. (Putnam \& Duke, 1978; Gatti, Perez \& Ferreira, 2007). The aqueous extract of Waltheria indica leaves was found to affect the number of germinated seeds of all test species (Figure 1a), while the aqueous extract of $W$. indica roots affected only L. sativa and H. chrysotrichus (Figure 1b). This may be associated with the fact that allelopathic substances affect species in different ways (Silva et al., 2021). Although the root extract did not directly affect the germination of the invasive weed $U$. brizantha, it was observed that its roots showed morphological differences in relation to the control and were shorter and thicker.

Figure 1. Percentage of germinated seeds in each of the treatments with aqueous extracts of Waltheria indica.
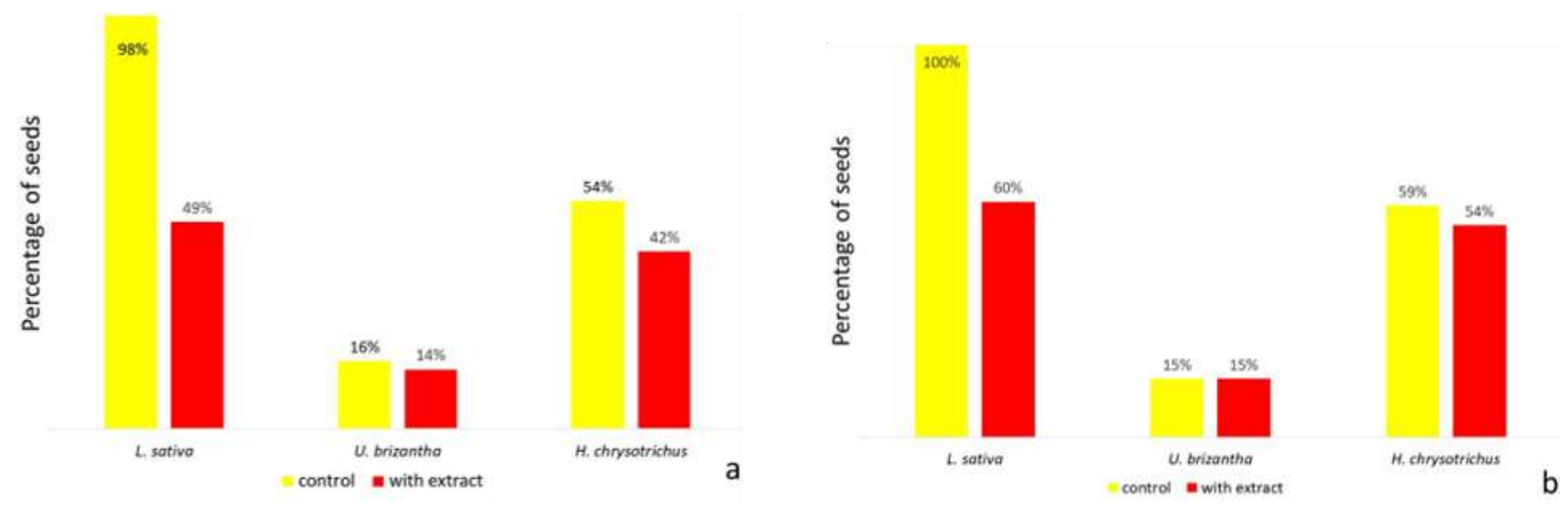

$\mathbf{a}$ - Treatment with aqueous extract of Waltheria indica leaves. $\mathbf{b}$ - Treatment with aqueous extract of Waltheria indica roots. Source: the authors.

The aqueous extract of $W$. indica leaves had an effect on the percentage of cell respiration in germinated seeds of $L$. sativa and $U$. brizantha (Figure 2a), whereas the aqueous extract of roots of $W$. indica affected only the percentage of cell respiration in L. sativa (Figure 2b). As already reported, the allelopathic effects can affect some part of the plant development (Putnam \& Duke, 1978; Piña-Rodrigues \& Lopes, 2001; Gatti, Perez \& Ferreira, 2007; Silva et al., 2021), and in the present study it was possible to verify, from the tetrazolium test, that even though the seeds germinated, the allelopathic substances affected the cellular respiration of the roots (Figure 3). 
Figure 2. Percentage of cellular respiration in the roots of Lactuca sativa and Urochloa brizantha species in each of the treatments with aqueous extracts of Waltheria indica.

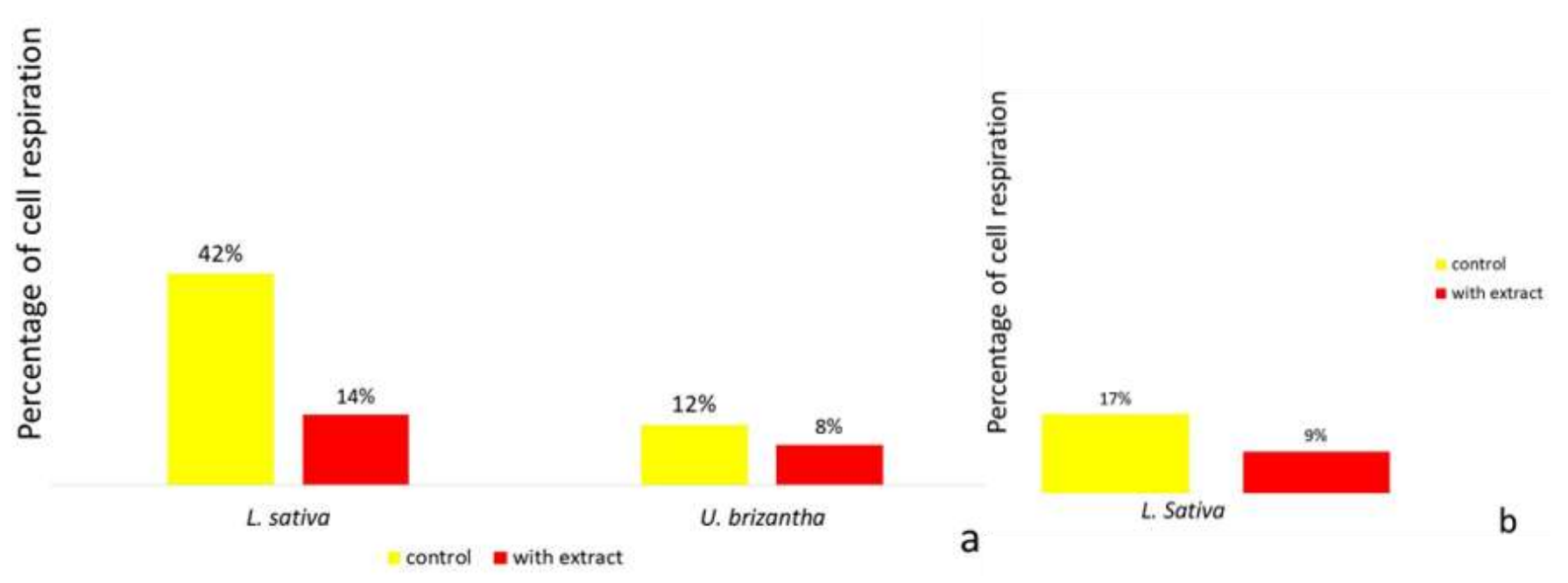

$\mathbf{a}$ - Treatment with aqueous extract of Waltheria indica leaves. $\mathbf{b}$ - Treatment with aqueous extract of Waltheria indica roots. Source: the authors.

Figure 3. Root coloration of Lactuca sativa L. submitted to the tetrazolium test at a concentration of $0.075 \%$ for 4 hours of immersion at a temperature of $25^{\circ} \mathrm{C}$.

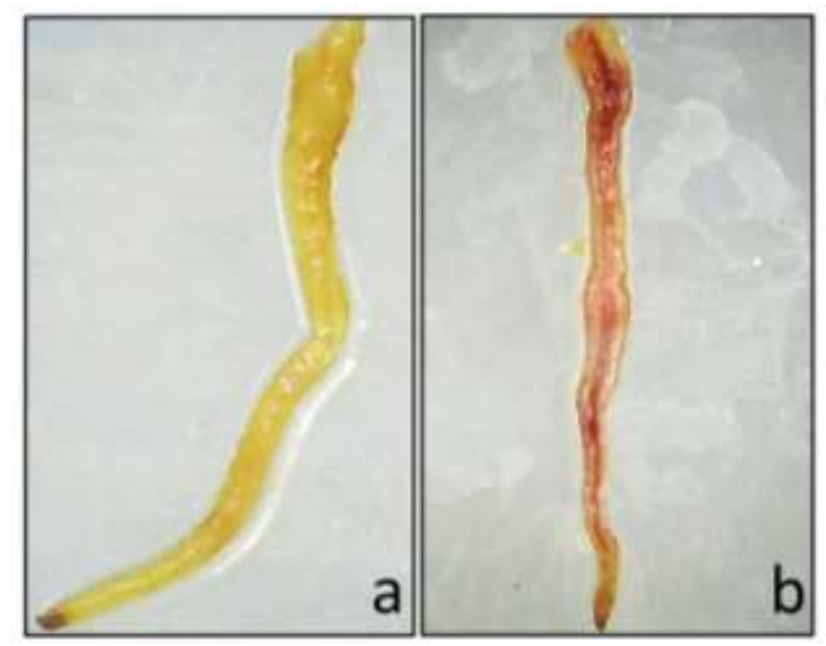

$\mathbf{a}$ - Dead tissue, indicated by the absence of staining (2x magnification). b - Tissues stained and alive (no magnification). Source: the authors.

The toxic effects of the aqueous extracts of $W$. indica go beyond just inhibiting germination; they are associated with death of the seedling roots evaluated. Many studies with allelopathic compounds bring considerations about the growth and development of the tested species (Silva et al., 2021), and many species end up germinating; however, the development is affected, and they cannot become normal adult plants (Da Rocha et al., 2018; Bernardes et al., 2020; Fioresi et al., 2021).

There was a significant difference $(\mathrm{p}<0.05)$ between the treatments and their respective controls only in the germination of L. sativa species in both extracts (Table 2). And for root respiration potential, significant difference (p<0.05) 
was found between treatments and their respective controls only for the roots of L. sativa species in both extracts (Table 3). All roots of $U$. brizantha and $H$. chysotrichus were dead in the bioassay with the aqueous extract of $W$. indica root.

Table 1. Significance values (p) of the Mann-Withney tests applied to verify difference in germination between the treatments and their controls.

\begin{tabular}{lccc}
\hline & \multicolumn{3}{c}{ Test Species } \\
\cline { 2 - 4 } Extract type & Lactuca sativa & Urochloa brizantha & Handroanthus chrysotrichus \\
\hline Aqueous leaf extract & $0.0001402^{*}$ & 0.666 & 0.1196 \\
Aqueous root extract & $0.0002238^{*}$ & 0.8455 & 0.4892 \\
\hline
\end{tabular}

* It means that the treatment with aqueous extract differed from the control.

Source: the authors.

Table 2. Significance values (p) of Mann-Withney tests applied to check for differences in root cell respiration between treatments and controls.

\begin{tabular}{lccc}
\hline & \multicolumn{2}{c}{ Test Species } \\
\cline { 3 - 4 } Extract type & Lactuca sativa & Urochloa brizantha & Handroanthus chrysotrichus \\
\hline Aqueous leaf extract & $0.000003799^{*}$ & 0.531 & 0.3337 \\
Aqueous root extract & $0.0001788^{*}$ & & \\
\hline
\end{tabular}

* It means that the treatment with aqueous extract differed from the control.

Source: the authors.

There was no difference $(\mathrm{p}>0.05)$ in germination of $L$. sativa seeds $(\mathrm{W}=37.5, \mathrm{p}=0.3603)$ between aqueous extracts of leaves and aqueous extract of roots (Figure 4A). The same was observed for the percentage of cellular respiration in $L$. sativa roots between aqueous leaf extracts and aqueous root extracts (Figure 4B). Since allelopathic compounds can be in all parts of the plant, especially in leaves and roots (Rice, 1984; Piña-Rodrigues \& Lopes 2001; Kremer et al., 2016; Ribeiro et al., 2019), W. indica was observed to possess toxicity in both, leaves and roots, as it showed no difference in germination. For cellular respiration percentage of the tested species, there the root extract caused the death of the roots of $U$. brizantha and $H$. chrysotrichus. 
Figure 4. Box-plot of the number of germinated seeds and the percentage of cellular respiration of the test species L. sativa in the different aqueous extracts.
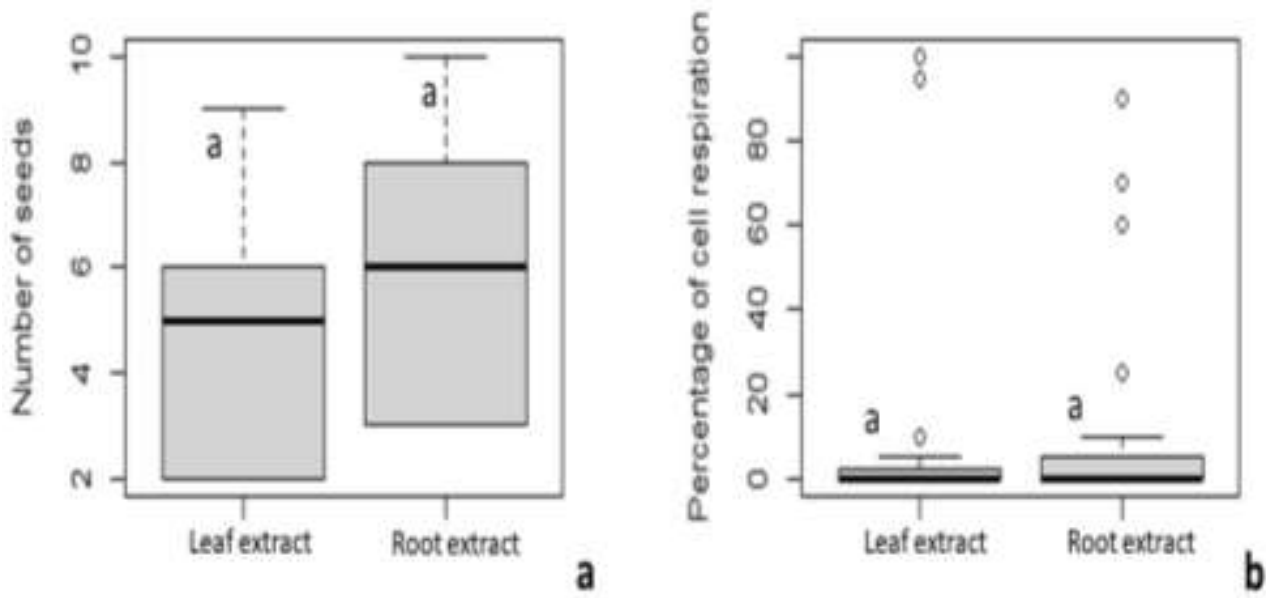

a - Number of germinated seeds per repetition for each of the treatments $\mathbf{b}$ - Percentage of cellular respiration in L. sativa roots in the different aqueous extracts.

Letter "a" shows that there was no difference between treatments at 5\% significance using the Mann-Whitney test.

Source: the authors.

\section{Conclusion}

The aqueous extracts of the leaves and roots of Waltheria indica affected the germination of the studied species, especially in Lactuca sativa. The absence of cellular respiration of seedling roots of the invasive $U$. brizantha reinforce the potential use of Waltheria indica to control weed, however it needs to be carefully examined since root extract also affected the native $H$. chrysotrichus. Therefore, we believed that the elucidation of the allelopathic compounds of $W$. indica may be an initial step for the study and development of bioherbicides to be produced in the future.

\section{Acknowledgments}

The authors thank the CAPES for providing research grants and the company AES Brasil, for providing all human and material resources for the field experiment; research assistants from CEIBA Consultoria Ambiental, for assisting in the collecting of the material in filed; Laboratório de Sementes e Mudas Florestais (LASEM) from UFSCar, for carrying out the experiment of seed germination under controlled conditions.

\section{References}

Bernardes, V. A. P., de Souza R. P. \& Alves, V. S. (2020) Aspectos do potencial alelopático do extrato aquoso das folhas de Mimosa ramosissima Benth, na germinação e crescimento inicial de Panicum maximum cv. aruana e Amaranthus retroflexus L. Research, Society and Development, 9(9), e691997757. http://dx.doi.org/10.33448/rsd-v9i9.7757

Brancalion, P. H. S., Niamir, A., Broadbent, E., Crouzeilles, R., Barros, F. S. M., Almeyda Zambrano, A. M., Baccini, A., Aronson, J., Goetz, S., Leighton Reid, J., Strassburg, B.B.N., Wilson, S., R.L. Chazdon, R. L., et al. (2019). Global restoration opportunities in tropical rainforest landscapes. Science Advances, 5. doi:10.1126/sciadv.aav3223

Calmon, M. (2021) Restauração de florestas e paisagens em larga escala: o Brasil na liderança global. Ciência e Cultura, 73(1). http://dx.doi.org/10.21800/2317-66602021000100009

Carmo, F. M. S., Borges, E. E. L. \& Takaki, M. (2007) Alelopatia de extratos aquosos de canela-sassafrás (Ocotea odorifera (Vell.) Rohwer). Acta Botanica Brasilica, 21, 697-705. https://doi.org/10.1590/S0102-33062007000300016

Climate-data.org. (2021) Dados meteorológicos do projeto OpenStreetMap, coletados entre 1982 e 2012. Available https://pt.climate-data.org/america-dosul/brasil/sao-paulo/cardoso-34983/. 
Copeland, S. M., Baughman, O. W., Boyd, C. S., Davies, K, W., Kerby, J., Kildisheva, O. A. \& Svejcar, T. (2021) Improving restoration success through a precision restoration framework. Restoration Ecology, 29(2), e13348. https://doi.org/10.1111/rec.13348

Cornish, P. S. \& Burgin, S. (2005) Residual Effects of Glyphosate Herbicide in Ecological Restoration. Restoration Ecology, 13(4), 695 - 702. https://doi.org/10.1111/j.1526-100X.2005.00088.x

da Rocha, V. D., dos Santos, T. A., Bispo, R. B., Zortéa, E. M. \& Rossi, A. A. B. (2018) Efeito alelopático de extratos aquosos de Solanum paniculatum L., na germinação e crescimento inicial de alface. Revista de Ciências Agroambientais, 16(1), 72-79. https://doi.org/10.5327/rcaa.v16i1.1805

da Silva, M. A. D., da Silva, J. N., Alves, M. R., Gonçalves, E. P. \& Viana, da S, J. (2021). Alelopatia de espécies da Caatinga. Research, Society and Development, 10(4), e57610414328-e57610414328. http://dx.doi.org/10.33448/rsd-v10i4.14328

di Sacco, A., Hardwick, K, A., Blakesley, D., Brancalion, P. H. S., Breman, E., Rebola, L. C., Chomba, S., Dixon, K., Elliot, S., Ruyonga, G., et al. (2021) Ten golden rules for reforestation to optimize carbon sequestration, biodiversity recovery and livelihood benefits. Global Change Biology, 27(7), 1328-1348. https://doi.org/10.1111/gcb.15498

Fioresi, R. S., Rodrigues Filho, J., Perin, I. T. A. L., da Silva, R. W., dos Santos, C. R., Corte, V. B. \& Frabça, H, S. (2021) Efeito alelopático de Solanum pimpinellifolium L. sobre a germinação e crescimento inicial de Lactuca sativa e Bidens pilosa. Scientia Plena, 17(6). https://doi.org/10.14808/sci.plena.2021.060201

França Neto, J.B., (1999) Teste de tetrazólio para determinação do vigor de sementes. In: Krzyzanowski, F.C.; Vieira, R.D.; França Neto, J.B. (Ed.). Vigor de sementes: conceitos e testes. Londrina: ABRATES, 218p.

García-Orth, X. \& Martínez-Ramos, M. (2011) Isolated trees and grass removal improve performance of transplanted Trema micrantha (L.) Blume (Ulmaceae) saplings in tropical pastures. Restoration Ecology, 19, 24-34. https://doi.org/10.1111/j.1526-100X.2009.00536.x

Iqbal, J., Rehmani, M. I. A., Sagheer, S., Kaleem, N. \& Munner, J. (2020) Herbicidal Potential of Some Dry Land Plants Against Lathyrus aphaca (L.), Winter Season Weed. Planta Daninha, 38. https://doi.org/10.1590/S0100-83582020380100001

Kremer, T. C. B., Yamashita, O. M., Felito, R. A., Ferreira, A. C. T. \& Araújo, C. F. (2016). Atividade alelopática de extrato aquoso de Croton glandulosus 1. na germinação e no desenvolvimento inicial de alface, Revista da Universidade Vale do Rio Verde, 14(1). http://dx.doi.org/10.5892/ruvrd.v14i1.2628

Koeppen, W. Climatología: con un estudio de los climas de la Tierra. Mexico City: Fondo de Cultura Economica; 1948.

Li, X. F., Wang, J., Huang, D., Wang, L. X., et al. (2011) Allelopathic potential of Artemisia frigida and successional changes of plant communities in the northern China steppe. Plant and Soil, 341(1), 383-398. ISSN: 0032-079X

Lopes, P. G., Salles, K. A., Oliveira, S. C. C., Sampaio, A. B. \&Schmidt, B. (2017) Evidence of phytotoxicity in a fast-growing shrub useful for savanna restoration in Central Brazil. Brazilian Journal of Botany, 40(3), 643-649. https://doi.org/10.1007/s40415-017-0381-4

Lovett, J. \& Ryuntyu, M. (1992) Allelopathy: broadening the context. In: Allelopathy. Springer, Dordrecht, 11-19.

Melo, E. C., Radünz, L. L. \& Melo, R. C. A. (2004) Influência do processo de secagem na qualidade de plantas medicinais-Revisão. Engenharia na Agricultura, 12(4), 307-315.

Passaretti, R. A., Pilon, N. A. L. \& Durigan, G. (2020) Weed control, large seeds and deep roots: Drivers of success in direct seeding for savanna restoration. Applied Vegetation Science, 23(3), p. 406-416. https://doi.org/10.1111/avsc.12495

Piña-Rodrigues, F. C. M., Lopes, B. M. (2001) Potencial alelopático de Mimosa caesalpinaefolia Benth sobre sementes de Tabebuia alba (Cham.) Sandw. Floresta e Ambiente, 8, 130-136.

Putnam, A R. \& Duke, W.B. (1978) Allelopathy in agroecosytems. Ann. Ver. Phytopathol. 16, 431-51.

Ribeiro, M. V., Valmorbida, R., Hartman, K. C. D., Porto, E. C., Almeida, J., Corsato, M, J. \& Fortes, A, M. T. (2019) Efeito alelopático de Leucaena leucocephala e Hovenia dulcis sobre germinação de Mimosa bimucronata e Peltophorum dubium. Iheringia, Série Botânica, 74 , e2019006. https://doi.org/10.21826/2446-82312019v74e2019006

Rice, E. L. (1984) Allelopathy. 2a edição. New York, EUA: Academic Press, 422p.

Rigon, C. A. G., Salamoni, A. T., Cutti, L. \& Aguiar, A. C. M. (2013). Potencial alelopático de extratos de mamoneira sobre a germinação e crescimento de azevém. Revista Tecnologia e Ciência Agropecuária7(2), 1-7.

Rodrigues, R.R.; Brancalion, P.H.S.; Isernhagen I. (2009) (Org.) Pacto pela restauração da Mata Atlântica: Referêncial dos conceitos e ações de restauração florestal. São Paulo: Instituto BioAtlântica. 256.

Rosa, D. M., Fortes, A. M. T., Palma, D., Marques, D. S., Corsato, J.M., Leszczynski, R. \& Mauli, M.M. (2007) Efeito dos extratos de tabaco, leucena e sabugueiro sobre a germinação de Pnicum maximum Jaqc. Revista Brasileira de Biociências 5(2): 444-446.

R Core Team. R: A language and environment for statistical computing. R Foundation for Statistical Computing, Vienna, Austria. Available at http://www.Rproject.org/.

Weidlich, E. W. A., Flórido, F. G., Sorrini, T. B. \& Brancalion, P. H. S. (2020) Controlling invasive plant species in ecological restoration: A global review. Journal of Applied Ecology, 57(9), 1806-1817. https://doi.org/10.1111/1365-2664.13656 